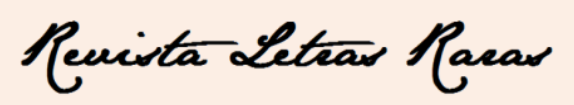

ISSN: 2317-2347 - Vol. 5, Ano 5, № 2 - 2016

\title{
E a certeza de que um dia você para mim...
}

José Veranildo Lopes da Costa Junior*

Rua Augusta - São Paulo.

Quinta-feira, 08 de setembro de 2016.

Às 09 da noite eu já estava na cama, pronto para dormir, quando a colega de quarto abriu lentamente a porta e me convidou para dividir umas bebidas na sala do hostel. Embora eu estivesse realmente cansado, considerei que aquele convite seria uma boa oportunidade para socializar com as outras pessoas que estavam hospedadas naquele lugar.

Enquanto conversávamos sobre a vida em São Paulo, uma das colegas do hostel enviou uma mensagem convidando mais uma pessoa para a social daquela noite. Por volta das 10 da noite a campainha toca. Com o celular na mão e um sorrido tímido o garoto do interior de São Paulo chegou. Sentou-se no sofá e imediatamente pediu a senha do Wi-Fi. Meu coração bateu mais forte. Respirei. Não hesitei e imediatamente me levantei e forneci a senha da Internet.

Do interior de São Paulo, morando no Rio, aquele menino de calça jeans, camisa branca e casaco jeans, não poderia ser mais um na multidão. Continuamos sentados no sofá da sala. Trocamos alguns olhares. Ele me perguntou se eu estava de férias em São Paulo. Respondi que a motivação daquela viagem era acadêmica. Ele sorriu. Continuamos com os celulares nas mãos.

Os colegas do hostel decidiram, então, passear pelas ruas paralelas à Avenida Paulista para comprar mais cervejas e, depois, encontrar um lugar para esticar a noite. Ainda na calçada do hostel, na Pamplona, iniciamos uma, ainda tímida, conversa. Os termômetros registravam 18 graus. As ruas estavam vazias. São Paulo surpreende. Um deserto paralelo à Avenida Paulista.

Aquele rapaz me dizia, com o sorriso nos olhos, que estudava jornalismo no Rio de Janeiro. Decidimos conversar sobre discurso. A semiótica me dizia que eu deveria ler aquele sorriso tímido. Caminhamos mais um pouco, e logo chegamos a um bar de esquina.

\footnotetext{
* Mestrando em Linguagem e Ensino pela Universidade Federal de Campina Grande (UFCG) e Licenciado em Letras - Língua Espanhola pela Universidade Estadual da Paraíba (UEPB). Contato: jveranildo@hotmail.com
} 


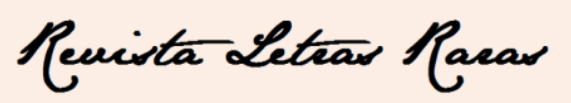

ISSN: 2317-2347 - Vol. 5, Ano 5, № 2 - 2016

Encostamos num carro azul. A conversa fluiu. Aquela voz me passava segurança. Seguimos caminhando. Compartilhamos uma bebida no mesmo copo. Decidimos passear um pouco mais pelas ruas cinzentas de São Paulo.

Ele se aproximou e se apoiou nos meus braços. Meu coração palpitou mais forte. Não sabia o que dizer, decidi apenas sentir o momento. Pouco tempo depois segurei na sua mão. Seguimos caminhando de mãos dadas pelas ruas de São Paulo.

Decidimos parar em frente a um restaurante chinês para descansar um pouco.

Naquela calçada a conversa continuou.

Os olhares.

A união de nossas mãos.

O frio da noite.

O desejo.

Nossos lábios se encontraram.

Narra-se a história de duas almas que por um instante se confundiram no silêncio da noite de São Paulo.

Logo mais a despedida.

E a certeza de que um dia você voltará pra mim.

Recebido em: 02/10/2016

Aceito em: 15/10/2016 